\title{
Fantazja czy rzeczywistość? Średniowieczny strój kata w wyobraźni Jana Matejki
}

Dziesięć tablic Ubiorów w Polsce 1200-17951, wydanych przez Jana Matejkę w 1860 r., obejmuje czasy od Bolesława Wstydliwego do Stanisława Augusta Poniatowskiego. Praca ma charakter patriotyczny i historyczny, co zostało potwierdzone przez kartę tytułową. Na każdej z dziesięciu tablic artysta namalował dziewięć grup: uczeni, szlachta, rycerstwo, duchowieństwo, król i dwór, magnaci, chłopi (czasem wśród nich pojawiają się portrety Żydów), mieszczanie, cechy i bractwa. Każda tablica opatrzona została datami wyznaczającymi okresy, w których dany strój obowiązywał: 1228-1333, 1333-1434, 1447-1492, 1507-1548, 1548-1572, 1576-1586, 1588-1632, 1633-1668, 1674-1696, 16971795. Daty ewidentnie „pogrupowane” zostały w oparciu o ważne wydarzenia polityczne z historii Polski. Nad konstrukcją samego albumu Matejko pracował przez około rok. Pracę ukończył 26 października $1860 \mathrm{r}$. Zbiegło się to z jego tragedią życiową, gdyż w tym samym dniu zmarł jego ojciec².

W grupie społecznej Cechy i bractwa został uchwycony kat, który - według objaśnień artysty - został namalowany na podstawie „dzieł obcych”’ Te skąpe

1 Pierwsze wydanie Ubiorów w Polsce ukazało się w 1860 r., w Krakowie. Zostało wydrukowane w drukarni i litografii „Czasu”, w kamienicy „Krzysztofory”, pod zarządem Masłowskiego. Wydanie drugie pojawiło się w 1875 r. nakładem samego autora, odbite w litografii Salba. Kolejne wydanie ukazało się po śmierci Jana Matejki w 1901 r. nakładem „Zakładu Fototechnicznego B. Wierzbicki i Ska”, pod zmienionym tytułem Ubiory w dawnej Polsce. Czwarte, ostatnie już wydanie Ubiorów w Polsce pochodzi z roku 1967 i ukazało się dzięki staraniom Wydawnictwa Literackiego w Krakowie.

2 J. Matejko, Ubiory w Polsce 1200-1795 [Wstęp, dobór ilustracji i podpisy opracował Edward Łepkowski], Kraków 1967, s. 13.

3 Jan Matejko w swoim albumie Ubiory w Polsce 1200-1795 zamieścił na marginesie adnotację do przedstawienia kata, w dokładnym brzmieniu $\mathrm{z}$ „dzieł obcych”. Zapis ten nie pozwala współczesnemu badaczowi sięgnąć do oryginałów, które były inspiracją dla artysty. 


\section{Anna Czajka}

informacje o źródłach nie pozwalają porównać tych wyobrażeń z oryginałem, który był przyczynkiem do odwzorowania. O ile stroje katowskie z lat 1228 1333 i 1333-1434 są uderzająco do siebie podobne, o tyle przedstawienie kata z lat 1447-1492 odbiega znacząco od poprzednich.

W wiekach średnich wojny, epidemie chorób i klęski żywiołowe spowodowały pewne oswojenie społeczeństwa ze śmiercią. Karę śmierci wykonywano publicznie ze względu na wymierzenie i zaprowadzenie sprawiedliwości lub chęć odstraszenia potencjalnych złoczyńców. „Spektakle śmierci” oprawione zostały w ramy ceremoniału, w którym każdorazowo główną rolę odgrywał kat-oprawca.

Prawdziwy rozwój tej krwawej profesji rozpoczął się wraz z lokowaniem miast na prawie niemieckim. Naturalną konsekwencją tego procesu było adaptowanie na terenach państwa polskiego prawodawstwa niemieckiego. W jego ramach sąd miał prawo wydawania wyroków śmierci, co skutkowało powołaniem stale działającego funkcjonariusza ${ }^{4}$, który wyroki te wykonywał. Witold Mails, znawca tematu sądownictwa w Polsce średniowiecznej, przyporządkował kata do grupy tzw. personelu pomocniczego. Nazewnictwo to podkreślało zawodowe wykonywanie obowiązków przez jej członków, w przeciwieństwie do osób piastujących urzędy z wyboru lub na podstawie nadania lennego. $\mathrm{Na}$ zachodzie Europy zawód kata był często dziedziczony. W Polsce powołanie urzędu oprawcy było następstwem kształtowania się na przestrzeni wieków XIII i XIV miejskiego immunitetu sądowego, a konkretnie przyznania ośrodkom miejskim, podporządkowanym przepisom niemieckim, prawa miecza (ius gladii ${ }^{5}$ ). Mieszkańcy miast, które uzyskały przywilej sądowy, byli częściowo lub zupełnie zwalniani z przepisów prawa polskiego. Dokumenty nadające miastom wspomniane prawo miecza precyzowały, jakie kary wolno było wykonywać na terenie danego ośrodka miejskiego ${ }^{6}$. Na ziemiach polskich, od lat trzydziestych XIII w. przez kilkaset lat, nader powszechne były przepisy prawa niemieckiego zwane Zwierciadłem Saskim7.

Prawdopodobnie pierwsza wzmianka o urzędzie kata pochodzi z księgi rady miejskiej Kazimierza z 1378 r. i widnieje w niej określenie tortori. Wiele wskazuje na to, że pod tą nazwą kryło się wynagrodzenie kata zatrudnianego $\mathrm{w}$ razie potrzeby z pobliskiego Krakowa (w stołecznym mieście o „mistrzu

$4 \quad$ H. Zaremska, Niegodne rzemiosło. Kat w społeczeństwie Polski XIV-XVI w., Warszawa 1986, s. 29, 84.

5 Prawo miecza - w średniowieczu prawo sądzenia spraw zagrożonych karą śmierci i prawo jej wykonania, przyznawane miastom i panom feudalnym.

6 Ibidem, s. 15-18.

7 S. Wrzesiński, Kata portret trumienny, „Focus Historia” 2007, nr 1, s. 22. 
śmierci" dowiadujemy się po raz pierwszy ze wzmianek datowanych na 1393 r. $)^{8}$. „Wypożyczanie” kata innej gminie miejskiej nie naruszało zasad pracy urzędu katowskiego, gdyż miasta te kierowały się tymi samymi przepisami sądowymi. Kat „w delegacji” był częstą alternatywą stosowaną przez ośrodki, które nie miały własnego „funkcjonariusza śmierci”. O powyższym świadczą zapisy w księgach rad miejskich, gdzie w rubryce przychodów pojawiają się tzw. tortoralia, czyli opłaty wnoszone przez miasta „wypożyczające” egzekutora. Posiadanie własnego oprawcy nakładało na miasto obowiązek wypłacania mu wynagrodzenia, pojedynczych opłat od wykonywanych egzekucji, w zależności od sposobu wykonywania oraz konieczność ponoszenia kosztów zakupu potrzebnych mu „narzędzi pracy” czy wydatków wynikających $\mathrm{z}$ ich uszkodzenia. W spisie budżetowym późnośredniowiecznego Poznania widnieje notatka o wypłaceniu wynagrodzenia dla katowczyka, czyli subtortori. Powyższe wzajemne zależności, łączące miasta macierzyste dysponujące stałym egzekutorem $\mathrm{z}$ jego czasowym najemcą, świadczą o istnieniu czegoś na wzór „unii katowskiej”. Kat wraz ze swoją żoną sprawował również nadzór nad domami publicznymi. Perspektywa zdobycia żony przez człowieka obłożonego infamią była niezwykle trudna - najczęściej zostawała nią zbrodniarka, która w ten sposób ratowała sobie życie. Dla kata był to często jedyny sposób zdobycia małżonki ${ }^{10}$. Ostatnią funkcją, która dołączyła do arsenału obowiązków kata w przestrzeni miejskiej były prace porządkowe ${ }^{11}$.

Kat jako ostatnie ogniwo wymiaru sprawiedliwości wykonywał trzy rodzaje kar: wyświecenie z miasta (konsekwencja banicji), kary cielesne oraz kary śmierci ${ }^{12}$. Kara śmierci znana była pod dwiema postaciami: zwykła (ścięcie, powieszenie, utopienie) oraz kwalifikowana (spalenie na stosie, łamanie kołem) ${ }^{13}$. W spektaklu śmierci kat odgrywał równie ważną rolę jak sam skazany. Podczas widowiska podlegał ocenzurowaniu dokonywanemu przez gapiów. Udane ścięcie było dowodem biegłości w profesji katowskiej i budziło uznanie $^{14}$. W nieudanych egzekucjach upatrywano wpływu sił nadprzyrodzonych i dowodu świadczącego o niewinności skazanego. W takim wypadku złość

\footnotetext{
H. Zaremska, Niegodne rzemiosło..., s. 21-22.

Ibidem, s. 20, 25, 27, 30.

10 S. Wałęga, O katach, hyclach i oprawcach $w$ dawnym Toruniu, „Rocznik Toruński” 1975 , t. 10, s. 280.

11 H. Zaremska, Niegodne rzemiosło..., s. 107.

12 Ibidem, s. 52.

13 M. Kober, Sposoby wykonywania kary śmierci w dawnych wiekach, „Prawo i Życie” 2000, nr 11, s. 75.

14 H. Zaremska, Niegodne rzemiosło..., s. 62.
} 


\section{Anna Czajka}

tłumu żądnego wrażeń kierowała się w stronę kata, który w ceremoniale reprezentował władzę i sprawiedliwość ${ }^{15}$. Pomiędzy tymi dwoma scenariuszami plasowało się przekupstwo ${ }^{16}$. Skazanych biorących udział w takim widowisku puszczano oczywiście wolno, choć czasami nie na długo ${ }^{17}$.

Torturowanie wprowadziło kata w tok działań sądowniczych, co dodatkowo powiększyło zakres jego obowiązków. Przesłuchiwanie mające na celu wymuszenie zeznań od przestępcy nie znajduje trwałego potwierdzenia w źródłach aż do XV w. ${ }^{18}$ Sytuacja ulega diametralnej zmianie, kiedy w XVI w. zaczęto spisywać tzw. księgi zeznań na mękach.

Kara wygnania z miasta miała zróżnicowaną wagę, która zależała od ram geograficznych banicji i czasu jej trwania. Wygnanie z miasta rozpoczynano od obwołania skazanego przez woźnych sadowych na rynku. „Procesji” wyprowadzającej go poza mury ośrodka towarzyszyła chłosta rózgami, wykonywana przez kata. Poza bramą miasta oprawca palił za przestępcą wiązkę słomy na znak odejścia wraz z nim nieprawości ${ }^{19}$.

Kat był znawcą ludzkiego ciała, co dodatkowo wzbudzało niemały respekt. Negatywna ocena zawodu przez ogół średniowiecznego społeczeństwa związana była z naganną przeszłością samego oprawcy, zdarzało się bowiem, że niekiedy sami byli ułaskawionymi przestępcami. W Polsce kat był identyfikowany z marginesem społecznym. Ze względu na swój zawód stykał się ze złoczyńcą, co skutkowało postrzeganiem oprawcy jako infamis. Samo przebywanie w obecności oprawcy, w czasie torturowania złoczyńcy, w izbie tortur (zwanych tortornia lub „męczarnia”) było jednoznaczne $\mathrm{z}$ utratą $\mathrm{Czci}^{20}$. Pogarda w stosunku do kata była także wyrażana „poza jego godzinami pracy". Pieczywo przeznaczone dla egzekutora było odwracane spodem do góry, a szklanka, z której w miejscu publicznym pił trunek stawała się jego własnością, gdyż nikt po człowieku nieczystym nie mógł używać tego samego naczynia ${ }^{21}$. W przestrzeni miejskiej przywileje kata kończyły się więc na bezpłatnie użytkowanym mieszkaniu², oddzielnej loży

15 M. Trzciński, Miecz katowski, pregierz, szubienica. Zabytki jurysdykcji karnej na Dolnym Śląsku (XIII-XVIII w.), Wrocław 2001, s. 237.

H. Zaremska, Niegodne rzemiosło..., s. 70

M. Kober, Sposoby wykonywania kary..., s. 75.

S. Wałęga, O katach..., s. 284-285.

19 H. Zaremska, Niegodne rzemiosło..., s. 52-53.

20 M. Kober, Sposoby wykonywania kary..., s. 74.

21 S. Wałęga, O katach..., s. 277.

22 Miasto pokrywało koszty ewentualnych materiałów i wydatków, związanych z remontem mieszkania katowskiego. Zdarzało się, że władze miejskie przeznaczały 
$\mathrm{z}$ kratą $\mathrm{w}$ kościele i prawie do corocznej spowiedzi ${ }^{23}$. Sprawą kontrowersyjną wydaję się stwierdzenie, że władze pokrywały koszty pochówku zmarłego funkcjonariusza śmierci ${ }^{24}$. Z powyższego wynika, że rysujący się obraz kata $\mathrm{w}$ średniowieczu był nie do pozazdroszczenia. Stanowiąc ostatnie ogniwo wymiaru sprawiedliwości, nie był obdarzony szacunkiem, jaki rozciągał się na inne urzędy związane z przestrzeganiem praworządności. Powszechnie budził strach i odrazę, czasem nawet większą niż sam skazany.

Po wybiciu wyznaczonej godziny skazaniec ubrany w śmiertelną koszulę (zakup jej zależał zapewne od zarządzeń kata) ${ }^{25}$, z zasłoniętymi oczami udawał się na egzekucję, która odbywać się mogła w dwóch miejscach: na rynku głównym miasta lub poza jego murami. Z tą ostatnią lokalizacją związana była kara śmierci przez powieszenie, która ze względu na sposób wykonania miała niezwykle hańbiący charakter ${ }^{26}$. Pohańbienie skazanego potęgował zwyczaj pozostawienia ciała wisielca aż do momentu jego rozkładu. Wspomniany teren egzekucji budził powszechną odrazę i strach, dlatego unikano kontaktu z tym miejscem.

„Mistrz sprawiedliwości” w odbiorze społecznym uchodził za człowieka niegodnego, niepoczciwego. Możemy domniemywać, że kat był osobą powszechnie rozpoznawalną przez społeczność lokalną, w której funkcjonował. Status ten zapewniło mu uczestnictwo w „widowisku śmierci”, które gromadziło rzeszę gapiów. Mimo tych spostrzeżeń, zapewne pojawiały się momenty, kiedy kat pozostawał anonimowy. Taka sytuacja mogła zaistnieć, gdy wybierał się do innego ośrodka w „delegację” w celu spełnienia swojej powinności lub kiedy stawał się nowo zatrudnionym funkcjonariuszem miejskim. Wskazane wydawałoby się wyróżnić z tłumu człowieka budzącego powszechną odrazę. Trafnym tego narzędziem był stój, który poprzez swoją nietypowość w pewien sposób piętnował swojego właściciela, kogoś, kto go nosi.

Jan Matejko na tablicach Ubiory w Polsce 1200-1795 przedstawił trzy wyobrażenia stroju kata w średniowieczu, opatrując je kolejno datami: 12281333, 1333-1434, 1447-1492. Pierwsza malarska wizja artysty przedstawia człowieka szczelnie odzianego od stóp do głów, z dominacją intensywnego

sumy na zasiedliny dla nowo przybyłego kata; T. Grabarczyk, Na gardle karanie. Kara śmierci w średniowiecznej Polsce, Warszawa 2008, s. 54.

23 H. Zaremska, Niegodne rzemiosło..., s. 107.

24 Ibidem, s. 29.

25 W. Maisel, Poznańskie prawo karne do końca XVI w., Poznań 1965, s. 124; M. Kober, Sposoby wykonywania kary..., s. 71.

26 M. Kober, Egzekutor sprawiedliwości. Urząd kata w Polsce, „Prawo i Życie” 2000, nr 1, s. 73. 


\section{Anna Czajka}

koloru czerwonego. Tunika katowska sięgała do bioder. Rękawy były poszerzane na odcinku pomiędzy barkiem a łokciem, zwężając się dopiero i przylegając do ciała na przedramieniu. Dodatkowo były ozdobione jasnymi, znacznej wielkości guzikami, które stanowią również ozdobę kaptura. Wspomniane zdobienie nakrycia głowy w postaci guzików znajdowało się pośrodku przedniej części kaptura, opinającej szyję i górną część klatki piersiowej. Na wysokości bioder tunika przewiązana jest szerokim pasem, na którym wiązano sznur szubieniczny. Oprawca ubrany jest w pantalony wciągnięte w spiczaste buty o dwóch rozcięciach z przodu. W lewej ręce trzyma miecz, którym zadawał śmiertelne ciosy swoim ofiarom.

Kolejna wizja Jana Matejki, przyporządkowana okresowi lat 1333-1434, stanowi wyraźną kontynuację poprzedniej. Czerwona tunika pozbawiona guzików zyskała zdobienie w postaci nacięć w dolnej jej części. Częściami składowymi stroju kata są nadal przylegające pantalony z nogawkami wpuszczonymi w buty $\mathrm{z}$ wywiniętym, ponacinanym materiałem, $\mathrm{w}$ takim samym stylu jak dół tuniki. Nowinką w garderobie kata jest peleryna sięgająca do kostek. Modyfikacji uległ kaptur oprawcy z wyłogiem na tors i spiczastym, zwężającym się ku dołowi, długim do pasa zakończeniem. Nie dziwi ponowne wyróżnienie przez artystę, spośród bogatego asortymentu narzędzi katowskich, miecza, który był niezbędny przy najczęściej wykonywanej w czasach średniowiecza karze śmierci przez ścięcie. Całość nadal pozostaje w kolorystyce czerwonej.

Wyobrażenia przedstawione przez Matejkę dla lat 1447-1492 znacząco różnią się od poprzednich. Poczynając od głowy, na której kaptur został zastąpiony czapką z małym rondem, wywiniętym na zewnątrz, po nakrycie wierzchnie w tonacji ciemnozielonej, przy szyi przyozdobionej kawałkiem czerwonego materiału, kończąc na wysokich spodniach w pionowe paski, w kolorystyce, na przemian, ciemnozielonej i czerwonej. Niezmiennym emblematem kata pozostał miecz, trzymany tym razem w prawej dłoni.

Miecz katowski pośród bogatego „arsenału” narzędzi do uśmiercania zajmował miejsce szczególne. Ścięcie w systemie prawnym było postrzegane jako kara honorowa, w pewnym sensie uprzywilejowana ${ }^{27}$. Wspomniany miecz katowski wywodzi się z tożsamej broni bojowej. Jego długość była zróżnicowana, choć - według badaczy - wynosiła przeciętnie $115 \mathrm{~cm}$. Cechą charakterystyczną miecza katowskiego była długa klinga, czyli jego głownia, która liczyła w przybliżeniu $80 \mathrm{~cm}$. Szerokość wahała się od 4 do $6 \mathrm{~cm}$. W zakończeniu

27 M. Trzciński, Miecz katowski, pregierz, szubienica..., s. 42-43; M. Kober, Sposoby wykonywania kary..., s. 71. 
klinga bywała prosto lub łukowato ścięta ${ }^{28}$. Miecze z rekonstrukcji Matejki na pierwszy rzut oka nie odbiegają od opisu badaczy, którzy stworzyli go na podstawie eksponatów muzealnych i odkryć archeologicznych.

Trudno zestawić wizję artysty z materiałem źródłowym, który traktowałby o stroju kata w średniowieczu. Z tego okresu pochodzą jedynie szczątkowe informacje. W dokumentach miejskich Krakowa widnieje wzmianka o obowiązku noszenia na ramieniu przez kata kawałków sukna koloru zielonego, czerwonego i białego. Na egzekucję ubierał się na czerwono, co świadczy o tym, że Matejkowska wizja przedstawia kata w czasie wykonywania zawo$\mathrm{du}^{29}$. Nakrycie głowy kata stanowił kaptur lekko opadający na twarz w celu stworzenia tajemniczego cienia, padającego na nią, co zostało ujęte w dwóch pierwszych wyobrażeniach Matejki. Czapki albo kapelusze poczęły powszechniej występować od schyłku średniowiecza, co potwierdza artysta swoją wizją $z$ lat 1437-1492. Niezbędnym elementem katowskiego stroju były rękawiczki ${ }^{30}$.

Kat w kapturze zakrywającym twarz - to obraz funkcjonujący w powszechnej świadomości. Jan Matejko na swoim słynnym obrazie Bitwa pod Grunwaldem umieścił kata trzymającego w ręce topór skierowany w stronę wielkiego mistrza Ulryka von Jungingena, by zadać mu „cios sprawiedliwości”, mszcząc się w ten sposób za krzywdy, jakich doznała Polska z rąk zakonu krzyżackiego. Plastyczne, a później także filmowe wizje przyczyniły się do powstania stereotypowego „uniformu” katowskiego, którego wiarygodności nie można potwierdzić ze względu na szczątkowe informacje o wyglądzie kata ${ }^{31}$.

Podejmując próbę odpowiedzi na zadane w tytule referatu pytanie - fantazja czy rzeczywistość w Matejkowskich przedstawieniach ubioru średniowiecznego kata? - wydaje się wniknięcie w schemat pracy malarza przy zbieraniu źródeł, na podstawie których przedstawił swoją wizję artystyczną. Za autentycznością przedstawionych ubiorów przemawia wnikliwa praca Matejki, polegająca na zbieraniu wszelkiego rodzaju materiałów pozwalających na rzetelne odzwierciedlenie przeszłości w stroju. Matejko rozpoczął swoją pracę od wykonywania rysunków, przerysów na kalkach, które były dla niego podstawą przy tworzeniu dzieła. Na treść wykonywanych rysunków składały się zabytki polskie i obce z ubiegłych stuleci - wytwory materialne,

28 W. Maisel, Dawne narzędzia wykonywania kar, „Kwartalnik Historii i Kultury Materialnej" 1969, nr 4, s. 697; M. Trzciński, Miecz katowski.., s. 52-53.

29 S. Wałęga, O katach..., s. 278.

30 S. Wrzesiński, Krwawa profesja. Rzecz o katach i ich ofiarach, Kraków 2006, s. 29-30; idem, Kat w dawnej Polsce, na Ślasku i Pomorzu, Kraków 2010, s. 29-30.

31 T. Grabarczyk, Na gardle karanie..., s. 56. 


\section{Anna Czajka}

związane z przemysłem artystycznym, rzeźbą, malarstwem, architekturą i sfragistyką. Za autentycznością wizji przemawiają również jego studia nad zbiorami Biblioteki Jagiellońskiej oraz wydawnictwami, które w jakikolwiek sposób poruszały tematykę ubioru w danych czasach. Osobisty skarbczyk malarz uzupełnił materiałami gromadzonymi przez badaczy historii kultury i zabytków polskich, m.in. Ambrożego Grabowskiego, Józefa Łepkowskiego i Józefa Muczkowskiego. W 1879 r. wydane zostały Objaśnienia dziesięciu tablic Ubiorów w Polsce, gdzie Matejko podał (dla większości przypadków) dokładne źródła, z których korzystał przy rysowaniu postaci należących do poszczególnych grup społecznych. Brakuje niestety informacji, na jakim materiale źródłowym wzorował się artysta przy rekonstrukcji stroju katowskiego. Trudno ostatecznie stwierdzić, czy było to przeoczenie, czy może celowy zabieg malarza, którego pobudek nie jesteśmy teraz w staniu odgadnąć. Brak świadectw z epoki decyduje o tym, że do końca nie możemy być pewni rekonstrukcji stroju katowskiego Jana Matejki.

\section{Bibliografia}

GRABARCZYK T., Na gardle karanie. Kara śmierci w średniowiecznej Polsce, Warszawa 2008.

KOBER M., Egzekutor sprawiedliwości. Urząd kata w Polsce, „Prawo i Życie” 2000, nr 11.

KOBER M., Sposoby wykonywania kary śmierci w dawnych wiekach, „Prawo i Życie” 2000, nr 11.

MAISEL W., Dawne narzędzia wykonywania kar, „Kwartalnik Historii Kultury Materialnej" 1969, nr 4.

MAISEL W., Poznańskie prawo karne do końca XVI w., Poznań 1965.

MATEJKO J., Ubiory $w$ Polsce 1200-1795 [Wstęp, dobór ilustracji i podpisy opracował Edward Łepkowski], Kraków 1967.

TRZCIŃSKI M., Miecz katowski, pręgierz, szubienica. Zabytki jurysdykcji karnej na Dolnym Śląsku (XIII-XVIII w.), Wrocław 2001.

WAŁĘGA S., O katach, hyclach i oprawcach w dawnym Toruniu, „Rocznik Toruński” 1975, t. 10.

WRZESIŃSKI S., Kat w dawnej Polsce, na Śląsku i Pomorzu, Kraków 2010.

WRZESIŃSKI S., Kata portret trumienny, „Focus Historia” 2007, nr 1.

WRZESIŃSKI S., Krwawa profesja. Rzecz o katach i ich ofiarach, Kraków 2006.

ZAREMSKA H., Niegodne rzemiosło. Kat w społeczeństwie Polski XIV-XVI w., Warszawa 1986. 


\section{Aneks}

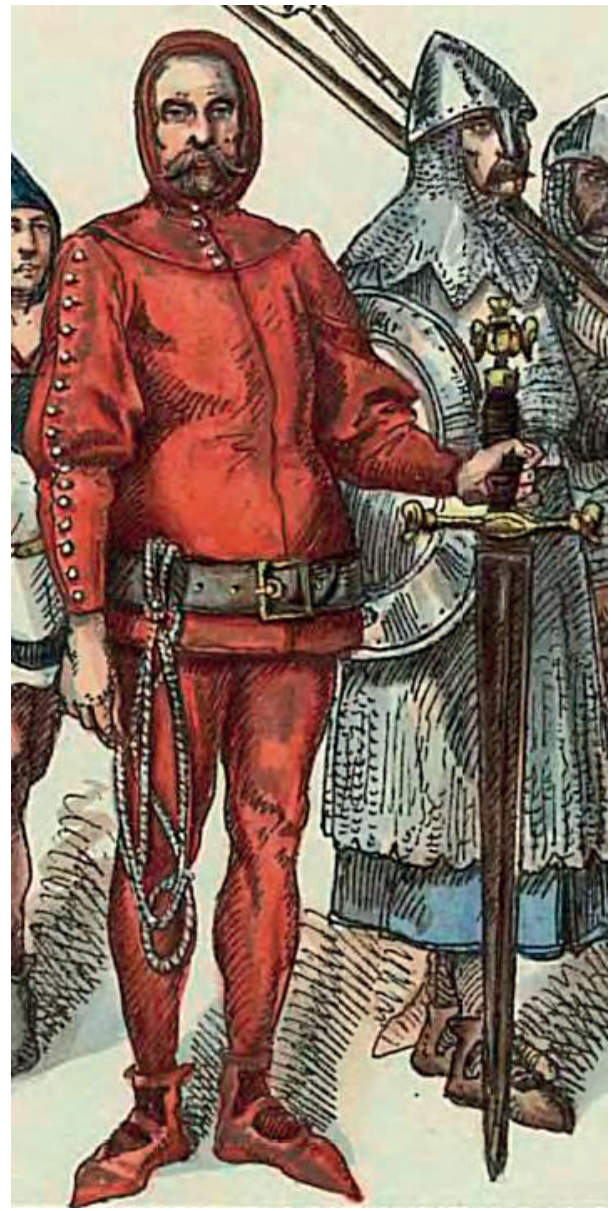

Ryc. 1. Kat 1228-1333.

Źródło: J. Matejko, Ubiory w Polsce 1200-1795, Kraków 1875 
Anna Czajka

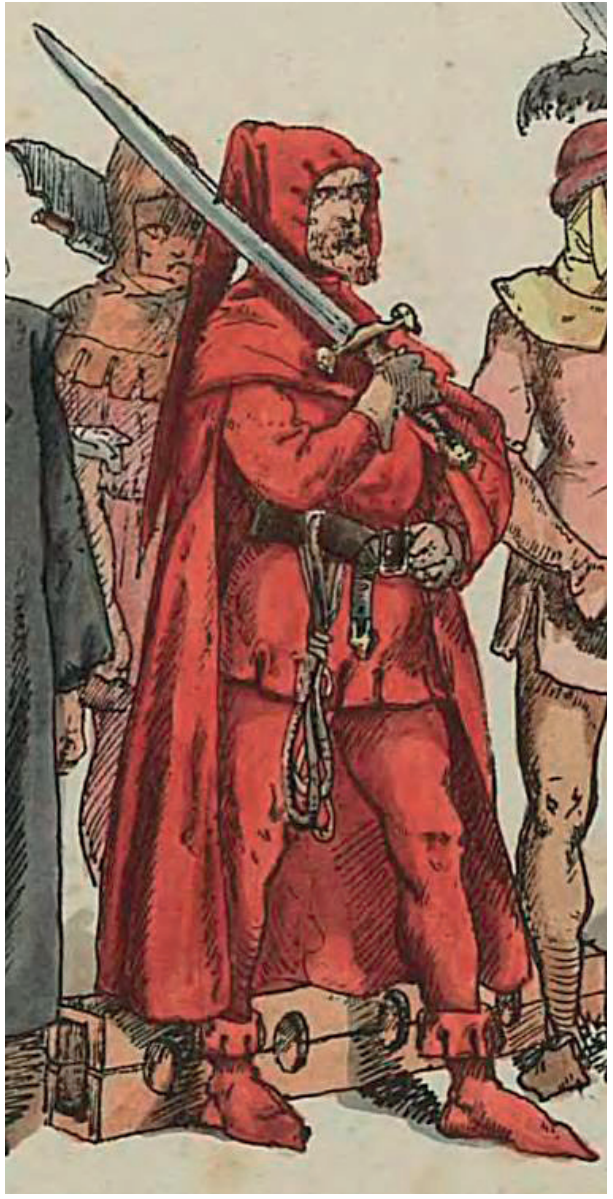

Ryc. 2. Kat 1333-1434.

Źródło: J. Matejko, Ubiory w Polsce 1200-1795, Kraków 1875

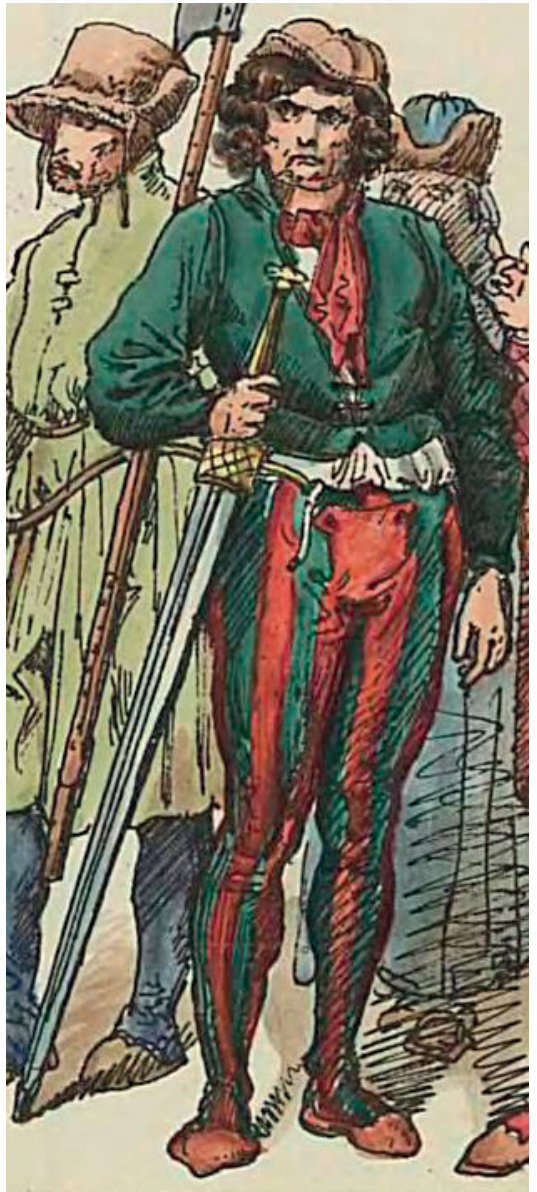

Ryc. 3. Kat 1447-1492.

Źródło: J. Matejko, Ubiory w Polsce 1200-1795, Kraków 1875 